\title{
Effects of particle size of processed barley grain, enzyme addition and microwave treatment on in vitro disappearance and gas production for feedlot cattle
}

\author{
Shin-ichi Tagawa ${ }^{1}$, Lucia Holtshausen², Tim A McAllister ${ }^{2}$, Wen Zhu Yang ${ }^{2}$, and Karen Ann Beauchemin ${ }^{2, *}$
}

* Corresponding Author: Karen Ann Beauchemin Tel: +1-403-317-2235, Fax: +1-403-317-2182,

E-mail: karen.beauchemin@agr.gc.ca

'Shimizuko shiryo Co., Ltd., Ishinomaki, Miyagi, 9813109, Japan

${ }^{2}$ Agriculture and Agri-Food Canada, Lethbridge, AB, T1J 4B1, Canada

Submitted May 3, 2016; Revised Jul 18, 2016; Accepted Aug 6, 2016
Objective: The effects of particle size of processed barley grain, enzyme addition and microwave treatment on in vitro dry matter (DM) disappearance (DMD), gas production and fermentation $\mathrm{pH}$ were investigated for feedlot cattle.

Methods: Rumen fluid from four fistulated feedlot cattle fed a diet of 860 dry-rolled barley grain, 90 maize silage and 50 supplement $\mathrm{g} / \mathrm{kg}$ DM was used as inoculum in 3 batch culture in vitro studies. In Experiment 1, dry-rolled barley and barley ground through a 1-, 2-, or 4-mm screen were used to obtain four substrates differing in particle size. In Experiment 2, cellulase enzyme (ENZ) from Acremonium cellulolyticus Y-94 was added to dry-rolled and ground barley (2-mm) at $0,0.1,0.5,1$, and $2 \mathrm{mg} / \mathrm{g}$, while Experiment 3 examined the interactions between microwaving $(0,30$, and $60 \mathrm{~s}$ microwaving) and ENZ addition $(0,1$, and $2 \mathrm{mg} / \mathrm{g})$ using dry-rolled barley and 2-mm ground barley.

Results: In Experiment 1, decreasing particle size increased DMD and gas production, and decreased fermentation $\mathrm{pH}(\mathrm{p}<0.01)$. The DMD $(\mathrm{g} / \mathrm{kg} \mathrm{DM})$ of the dry-rolled barley after $24 \mathrm{~h}$ incubation was considerably lower $(\mathrm{p}<0.05)$ than that of the ground barley $(119.1$ dry-rolled barley versus 284.8 for $4-\mathrm{mm}$, 341.7 for 2-mm; and 358.6 for 1-mm). In Experiment 2, addition of ENZ to dry-rolled barley increased DMD $(p<0.01)$ and tended to increase $(p=0.09)$ gas production and decreased $(\mathrm{p}<0.01)$ fermentation $\mathrm{pH}$, but these variables were not affected by ENZ addition to ground barley. In Experiment 3, there were no interactions between microwaving and ENZ addition after microwaving for any of the variables. Microwaving had minimal effects (except decreased fermentation $\mathrm{pH}$ ), but consistent with Experiment 2, ENZ addition increased $(\mathrm{p}<0.01) \mathrm{DMD}$ and gas production, and decreased $(\mathrm{p}<0.05)$ fermentation $\mathrm{pH}$ of dry-rolled barley, but not ground barley.

Conclusion: We conclude that cellulase enzymes can be used to increase the rumen disappearance of barley grain when it is coarsely processed as in the case of dry-rolled barley. However, microwaving of barley grain offered no further improvements in ruminal fermentation of barley grain.

Keywords: Barley Grain; Enzyme; Gas Production; In vitro Dry Matter Disappearance; Particle Size; Rumen Fluid

\section{INTRODUCTION}

In 2014, global production of cereal grains included 990 million metric tonnes (mt) of corn, 717 million $\mathrm{mt}$ of wheat, 478 million $\mathrm{mt}$ of rice, and 145 million $\mathrm{mt}$ of barley [1]. Barley is an important crop for animal production [2] and its utilization has been widely investigated for pigs [3], poultry [4,5], dairy cows [6] and beef cattle [7]. Koenig et al [7] reported microbial protein synthesis and nutrient digestibility of beef cattle fed barley-based diets containing from 743 to $893 \mathrm{~g} / \mathrm{kg}$ dry matter (DM) barley. 
Digestibility of whole barley grain by cattle is limited by the presence of its fibrous hull and intact pericarp, which can prevent bacterial attachment and digestion in the rumen [8]. Fracturing of the pericarp through grain processing is necessary to allow rumen bacteria to gain access to the rapidly digestible nutrients of the endosperm [9]. Consequently, rumen fermentation of barley grain by ruminants is affected by particle size resulting from processing, with extensive processing maximizing rumen availability. However, extensive processing can be costly and can increase the incidence of rumen acidosis in cattle [10]. Therefore, alternative technologies such as enzymes and heat-treatment may help optimize the efficiency of barley grain utilization by ruminants.

Use of fibrolytic enzyme additives may provide a unique opportunity to increase the ruminal digestibility of barley grain [11], particularly when grain is minimally processed. The barrier to microbial digestion created by the hull and beta-glucan within the endosperm may be eliminated in part by fiber degrading enzymes, thereby increasing access of ruminal microbes to the inner, more digestible starch with the endosperm [9]. Krause et al [11] showed that exogenous fibrolytic enzymes improved nutrient digestion by feedlot cattle fed high-concentrate diets that contained barley grain.

Processing using methods such as steam-rolling and steamflaking, in which heat and moisture are applied to grain, can help gelatinize starch and may increase degradation by microorganisms in the rumen [2]. A less expensive alternative to these heat treatments may be microwaving. Microwaving of barley grain has been shown to increase ruminal starch degradability [12]. However, feed grains are not routinely microwaved commercially in part because beneficial effects have not been widely identified.

The aim of the study was to investigate interactions between particle size, microwaving and the application of cellulases to barley grain. We hypothesized that microwave treatment would improve in vitro disappearance of barley grain, especially when subjected to fibrolytic enzyme additives, and that this combination of treatments would reduce the degree of particle size reduction needed to optimize rumen availability of barley.

\section{MATERIALS AND METHODS}

\section{Animals and diets}

Three in vitro batch culture experiments were conducted. In Experiments 1 and 2, rumen fluid (1 L per animal) was collected from four ruminally cannulated steers (average body weight, $645 \mathrm{~kg}$; average rumen fluid pH, 5.9). In Experiment 3, rumen fluid was collected from two ruminally cannulated steers (average body weight, $700 \mathrm{~kg}$; average rumen fluid $\mathrm{pH}, 6.4$ ). The $\mathrm{pH}$ of rumen fluid was measured immediately after sampling using a pH meter (B20PI, SympHony Benchtop Meters; VWR, Edmonton, $\mathrm{AB}$, Canada).
All steers were fed a total mixed diet for ad libitum consumption containing 860 dry-rolled barley grain, 90 maize silage, and 50 supplement $\mathrm{g} / \mathrm{kg}$ DM basis. The steers had free access to water and a mineral block throughout the experiment. Rumen fluid was obtained before feeding, strained through 4 layers of cheesecloth into an insulated thermos and immediately transferred to the laboratory. Steers were cared for according to the guidelines of the Canadian Council on Animal Care (Ottawa, ON, Canada).

Experimental design, substrates and treatments

Experiment 1: In vitro batch culture incubations were performed to investigate effects of particle size reduction due to processing of barley grain on in vitro DM disappearance (DMD), gas production and fermentation $\mathrm{pH}$. The study was conducted as a completely randomized design with four treatments (dry-rolled barley, 1-, 2-, and 4-mm barley) in two runs (each using pooled rumen fluid from 2 steers), with 3 replications per run. A sample of dry-rolled feed grade barley was obtained from the feed mill at the Lethbridge Research and Development Center (Lethbridge, $\mathrm{AB}$, Canada). The sample contained $870 \mathrm{~g} / \mathrm{kg}$ of DM comprised of 979 organic matter, 112 crude protein, 679 starch, and 281 neutral detergent fiber (aNDF) $\mathrm{g} / \mathrm{kg}$. The dry-rolled barley was then ground through a 1-, 2-, or 4-mm screen (SM100, Retsch $\mathrm{GmbH}$, Haan, Germany).

Experiment 2: Dry-rolled barley and barley ground through a 2-mm screen from Experiment 1 were used to investigate effects of enzyme addition on in vitro DMD, gas production and fermentation $\mathrm{pH}$. The study was performed as a completely randomized design with treatments arranged as a 2 (dry-rolled and 2-mm barley $) \times 5(0,0.1,0.5,1$, and $2 \mathrm{mg} / \mathrm{g}$ fresh matter [FM] of enzyme) factorial in two runs (each using pooled rumen fluid from 2 steers), with 3 replications per run. The enzyme (ENZ) powder was from Acremonium cellulolyticus Y-94 (Meiji Seika Pharma Co., Ltd., Tokyo, Japan). Activity was assayed by the manufacturer as 1,120 units/g microcrystalline cellulose and 7,460 units/g carboxymethyl cellulose at $\mathrm{pH}$ 5.6. In addition, this organism is known to express other fibrolytic activities, such as xylanase, $\beta$-glucosidase, $\beta$-xylosidase, and mannanase [13]. To add ENZ at the desired rates $0.4,2,4$, and $8 \mathrm{~g} / \mathrm{L}$ solutions were prepared with distilled water and the appropriate solution was applied at $0.25 \mathrm{~mL} / \mathrm{g}$ barley $\mathrm{FM}$, so as to add $\mathrm{ENZ}$ at a rate of $0.1,0.5$, 1 , and $2 \mathrm{mg} / \mathrm{g}$ FM of both ground or dry-rolled barley.

Experiment 3: In vitro batch culture incubations were performed with dry-rolled barley and 2-mm ground barley using a completely randomized design with treatments arranged as a $3(0,30$, and $60 \mathrm{~s}$ microwaving $) \times 3(0,1$, and $2 \mathrm{mg}$ ENZ/g FM) factorial in a single run, with 3 replications per run. Only a single run was performed because the steers were no longer available.

Dry-rolled and ground barley samples from Experiment 2 were subjected to heating using a household microwave oven (Model DMW 799W, normal maximum output power $700 \mathrm{w}$; 
Dandy Products Ltd, Guelph, ON, Canada) for the desired times. Following microwaving, all samples were cooled to room temperature. The ENZ used in Experiment 2 was added at the desired rates using solutions $(0,4$, and $8 \mathrm{~g} / \mathrm{L}$, respectively) prepared with distilled water applied at $0.25 \mathrm{~mL} / \mathrm{g}$ barley fresh weight after microwaving.

\section{In vitro disappearance, gas production and fermentation $\mathrm{pH}$ procedures}

In vitro $\mathrm{DMD}$, gas production and fermentation $\mathrm{pH}$ were measured for each replicate of each treatment within each experiment. Approximately $1.0 \mathrm{~g}$ samples (fresh weight) were weighed into Ankom F57 fiber bags and three empty bags were used as blanks within each run. The appropriate amounts of ENZ were added to the individual barley samples within the filter bags and left over night. The bags with sample were sealed (Model H-306, Impulse, Uline, Pleasant Prairie, WI, USA) and placed into 100 $\mathrm{mL}$ serum bottles.

The incubations were conducted as described by Anele et al [14]. Strained rumen fluid $(20 \mathrm{~mL})$ and pre-warmed buffer solution $(60 \mathrm{~mL},[15])$ were added into $100 \mathrm{~mL}$ serum bottles under $\mathrm{CO}_{2}$. Bottles and bags without barley (and with enzyme) were used as blanks. Bottles were incubated at $39^{\circ} \mathrm{C}$ in an incubator (Model 1915, VWR Reach-In Incubator, Sheldon Manufacturing Inc., Comelius, OR, USA) for 1, 3, 6, and $24 \mathrm{~h}$ for Experiment $1,24 \mathrm{~h}$ for Experiment 2, and 6 and $24 \mathrm{~h}$ for Experiment 3 . After completing the incubation, bottles were placed in an ice water bath to impede microbial activity. Bags were removed from the vials, washed and dried in an oven at $55^{\circ} \mathrm{C}$ to determine DMD. The $\mathrm{pH}$ of the incubation medium was measured with a $\mathrm{pH}$ meter.

Gas production was investigated after $1,3,6$, and $24 \mathrm{~h}$ in Experiment 1, after $24 \mathrm{~h}$ in Experiment 2, and after 6 and $24 \mathrm{~h}$ in Experiment 3. Headspace gas production was measured after $1,3,6,14$, and $24 \mathrm{~h}$ by inserting a needle $(25$ gage $\times 22.2 \mathrm{~mm}$, Becton, Dickinson and Company, Franklin Lakes, NJ, USA) attached to a pressure transducer (Model3462 Fisher scientific, Pittsburgh, PA, USA). The gas was released from the bottles after measurement. Pressure values (p), corrected for gas released from the blanks were used to generate volume estimates using the equation of Mauricio et al [16].

$$
\text { Gas production }(\mathrm{mL})=0.18+3.697 \times \mathrm{p}+0.0824 \times \mathrm{p}^{2}
$$

\section{Chemical analysis}

The original dry-rolled barley sample was ground through a 2-mm screen to estimate analytical DM and ash as described by AOAC [17] and aNDF as described by Van Soest et al [18] using heat-stable á-amylase (Termamyl 120 L, Novo Nordisk Biochem, Franklinton, NC, USA). The sample was ground finer (MM400, Retsch GmbH, Germany) prior to crude protein and starch analysis. The crude protein content $(\mathrm{N} \times 6.25)$ of samples was determined by flash combustion, chromatographic separation, and thermal conductivity (Carlo Erba Instruments, Milan, Italy). Starch was determined by enzymatic hydrolysis of alpha linked glucose polymer as described by Rode et al [6].

\section{Statistical analysis}

Data in Experiment 1 for in vitro DMD, gas production and fermentation $\mathrm{pH}$ at each incubation time were analyzed using the MIXED procedure of SAS (SAS Institute, Inc., Cary, NC, USA) with grain processing treatment (barleys ground through $1-, 2-$, and 4-mm screens and dry-rolled barley grain) as a fixed effect in the model. When the effect of grain processing was significant $(\mathrm{p}<0.05)$, treatments were compared using least significant differences. Data in Experiment 2 for DMD, gas production and fermentation $\mathrm{pH}$ were analyzed separately for dry-rolled and ground barley using the MIXED procedure of SAS with a model that included the fixed effect of enzyme treatment $(0,0.1$, $0.5,1$, and 2, mg/g FM). In Experiment 3, data for the same variables as above were analyzed for dry-rolled and ground barley separately using a mixed model that included the effects of microwaving (0, 30, and $60 \mathrm{~s})$, ENZ addition ( 0,1 , and $2 \mathrm{mg} / \mathrm{g}$ FM) and their interaction. Orthogonal polynomial contrasts (linear and quadratic) were used to examine effects of enzyme dose (Experiments 2 and 3) and duration of microwaving. Significant effects of treatment were declared at $\mathrm{p}<0.05$ and tendencies at $0.05<\mathrm{p}<0.10$.

\section{RESULTS}

\section{Particle size of barley (Experiment 1 )}

Processing affected in vitro DMD after all incubation times $(\mathrm{p}<0.01$, Table 1). After 1 and $3 \mathrm{~h}, \mathrm{DMD}$ of barley ground through 1 - and 2-mm screens was greater than for other barleys. There was no disappearance of the dry-rolled barley until after $6 \mathrm{~h}$. After $6 \mathrm{~h}, \mathrm{DMD}$ of 1-mm barley was still greater than dry-rolled and 4-mm barleys, but the DMD of the 2-mm barley was only greater than that of dry-rolled barley. After $24 \mathrm{~h}, \mathrm{DMD}$ of all three ground barleys were similar, all of which were greater than for dry-rolled barley.

Gas production from the four barleys tended to differ after $1 \mathrm{~h}(\mathrm{p}=0.053)$, and differed after 3 and $24 \mathrm{~h}$ of incubation with the main difference being lower gas production from dry-rolled barley. The fermentation $\mathrm{pH}$ only differed among barleys after $24 \mathrm{~h}$ of incubation $(\mathrm{p}<0.01)$, with $\mathrm{pH}$ being greater for dry-rolled barley than for the other three barleys.

\section{Enzyme addition and particle size of barley (Experiment} 2)

The effect of ENZ differed for dry-rolled and ground barley. With dry-rolled barley, addition of ENZ increased (linear, $\mathrm{p}<0.01$ ) the 24 -h DMD in a quadratic manner ( $\mathrm{p}=0.04$; Table 2$)$. There was only a linear trend $(\mathrm{p}=0.09)$ for differences in gas produc- 
Table 1. In vitro DM disappearance (DMD), gas production and fermentation pH of dry-rolled and ground barley (Experiment 1)

\begin{tabular}{|c|c|c|c|c|c|c|}
\hline \multirow{2}{*}{ Incubation time } & \multicolumn{3}{|c|}{ Screen size of ground barley } & \multirow{2}{*}{ Dry-rolled barley } & \multirow{2}{*}{ SEM } & \multirow{2}{*}{$p$} \\
\hline & 1-mm & 2-mm & 4-mm & & & \\
\hline \multicolumn{7}{|l|}{ DMD (g/kg DM) } \\
\hline 1 & $52.7^{\mathrm{a}}$ & $50.0^{\mathrm{a}}$ & $7.7^{\mathrm{b}}$ & $0.0^{b}$ & 0.6 & $<0.01$ \\
\hline 3 & $161.3^{\mathrm{a}}$ & $118.8^{\mathrm{a}}$ & $54.5^{b}$ & $0.0^{c}$ & 1.4 & $<0.01$ \\
\hline 6 & $118.7^{\mathrm{a}}$ & $113.8^{\mathrm{ab}}$ & $80.7^{b}$ & $0.0^{c}$ & 1.1 & $<0.01$ \\
\hline 24 & $358.6^{\mathrm{a}}$ & $341.7^{\mathrm{a}}$ & $284.8^{\mathrm{a}}$ & $119.1^{b}$ & 2.5 & $<0.01$ \\
\hline \multicolumn{7}{|c|}{ Gas production (mL/g DM) } \\
\hline 1 & $5.1^{\mathrm{ab}}$ & $5.0^{\mathrm{ab}}$ & $6.9^{\mathrm{a}}$ & $3.3^{b}$ & 0.5 & 0.053 \\
\hline 3 & $10.8^{\mathrm{a}}$ & $9.5^{\mathrm{ab}}$ & $4.7^{\mathrm{ab}}$ & $1.4^{c}$ & 1.0 & $<0.01$ \\
\hline 6 & 23.0 & 29.9 & 18.8 & 12.5 & 2.5 & 0.26 \\
\hline 24 & $61.7^{\mathrm{a}}$ & $55.7^{\mathrm{a}}$ & $42.2^{\mathrm{a}}$ & $20.0^{b}$ & 4.2 & $<0.01$ \\
\hline \multicolumn{7}{|l|}{ Fermentation $\mathrm{pH}$} \\
\hline 1 & 5.77 & 5.76 & 5.77 & 5.80 & 0.04 & 0.999 \\
\hline 3 & 5.66 & 5.68 & 5.70 & 5.73 & 0.03 & 0.91 \\
\hline 6 & 5.58 & 5.59 & 5.62 & 5.69 & 0.04 & 0.82 \\
\hline 24 & $5.43^{b}$ & $5.44^{b}$ & $5.50^{b}$ & $5.69^{a}$ & 0.04 & $<0.01$ \\
\hline
\end{tabular}

DM, dry matter; SEM, standard error of means; $p$, probability.

Means within a row with different letters differ $(p<0.05)$.

tion, but fermentation $\mathrm{pH}$ decreased linearly $(\mathrm{p}<0.01)$ with enzyme addition, although the magnitude of change was small. With ground barley, ENZ addition had no effects on the variables measured.

\section{Particle size, microwave treatment, and enzyme addition} (Experiment 3)

There were no interactions between microwaving and enzymes, so only the main treatment effects are presented (Table 3). Addition of ENZ to dry-rolled barley linearly increased $(p<0.01)$ DMD and gas production and linearly decreased $(p<0.05)$ fermentation $\mathrm{pH}$. The effects of ENZ occurred after both 6 and $24 \mathrm{~h}$ of incubation for these variables. In contrast, the effects of ENZ added to ground barley were limited to increased gas production after $6 \mathrm{~h}$ (linear effect, $\mathrm{p}=0.03$ ), and decreased fermentation $\mathrm{pH}$ after $6 \mathrm{~h}$ (linear effect, $\mathrm{p}=0.051$; quadratic effect, $\mathrm{p}<0.01$ ) and $24 \mathrm{~h}$ (linear effect, $\mathrm{p}=0.047$ ) of incubation.

For both ground and dry-rolled barley, microwave treatment had no effects on DMD. There was a linear trend $(\mathrm{p}=0.055)$ for increased gas production for dry-rolled barley after $24 \mathrm{~h}$ incubation, but not for ground barley. For dry-rolled barley, fermentation $\mathrm{pH}$ after $6 \mathrm{~h}$ decreased quadratically and linearly ( $\mathrm{p}=0.02$, respectively) with microwaving, and after $24 \mathrm{~h}$ of incubation only quadratic $(\mathrm{p}=0.01)$ effects on $\mathrm{pH}$ were noted. However, with ground barley, there was only a trend $(p=0.09)$ for decreased fermentation $\mathrm{pH}$ at $6 \mathrm{~h}$ of incubation with microwaving.

\section{DISCUSSION}

It is well known that the source of rumen inoculum can affect the results of in vitro incubations, and thus it is recommended that donor animals be fed a diet that includes the substrate used in the in vitro assay [19]. Thus, in the present study rumen fluid from feedlot cattle fed a diet comprised of $860 \mathrm{~g} / \mathrm{kg}$ DM dry-rolled barley grain was used. The $\mathrm{pH}$ of rumen fluid collected before

Table 2. The effect of enzyme on in vitro dry matter disappearance (DMD), gas production and fermentation pH of dry-rolled barley and barley ground through a 2-mm screen incubated for $24 \mathrm{~h}$ (Experiment 2)

\begin{tabular}{|c|c|c|c|c|c|c|c|c|}
\hline & \multicolumn{5}{|c|}{ Enzyme addition (mg/g FM) } & \multirow{2}{*}{ SEM } & \multicolumn{2}{|c|}{$p$} \\
\hline & 0 & 0.1 & 0.5 & 1 & 2 & & L & Q \\
\hline \multicolumn{9}{|l|}{ Dry-rolled barley } \\
\hline Gas production (mL/g DM) & 26.4 & 27.2 & 26.0 & 28.9 & 25.1 & 1.28 & 0.09 & 0.42 \\
\hline Fermentation $\mathrm{pH}$ & 5.66 & 5.67 & 5.66 & 5.62 & 5.59 & 0.02 & $<0.01$ & 0.67 \\
\hline \multicolumn{9}{|c|}{ Barley ground through a 2-mm screen } \\
\hline Fermentation pH & 5.39 & 5.37 & 5.34 & 5.33 & 5.37 & 0.01 & 0.69 & 0.31 \\
\hline
\end{tabular}

Enzyme, cellulase prepared from Acremonium cellulolyticus Y-95; FM, fresh matter; SEM, standard error of means; p, probability; L, linear; Q, quadratic; DM, dry matter. 
Table 3. The effect of microwave and enzyme addition on in vitro dry matter disappearance (DMD), gas production and fermentation pH of dry-rolled barley and barley ground through a 2-mm screen incubated for 6 and $24 \mathrm{~h}$ (Experiment 3)

\begin{tabular}{|c|c|c|c|c|c|c|c|c|c|c|c|}
\hline & \multicolumn{3}{|c|}{ Enzyme (mg/g FM) } & \multicolumn{2}{|c|}{$\mathrm{p}$} & \multicolumn{3}{|c|}{ Microwave (s) } & \multirow{2}{*}{ SEM } & \multicolumn{2}{|c|}{$\mathrm{p}$} \\
\hline & 0 & 1 & 2 & $\mathrm{~L}$ & $Q$ & 0 & 30 & 60 & & L & Q \\
\hline \multicolumn{12}{|c|}{ Dry-rolled barley } \\
\hline $6 \mathrm{~h}$ & 69.0 & 89.4 & 117.4 & $<0.01$ & 0.74 & 80.8 & 104.3 & 90.8 & 0.63 & 0.45 & 0.11 \\
\hline $24 \mathrm{~h}$ & 148.9 & 195.9 & 210.3 & $<0.01$ & 0.28 & 191.6 & 187.5 & 176.0 & 0.84 & 0.36 & 0.80 \\
\hline \multicolumn{12}{|c|}{ Gas production } \\
\hline \multicolumn{12}{|c|}{ Fermentation $\mathrm{pH}$} \\
\hline $6 \mathrm{~h}$ & 6.19 & 6.16 & 6.15 & $<0.01$ & 0.37 & 6.19 & 6.15 & 6.16 & 0.01 & 0.02 & 0.02 \\
\hline $24 \mathrm{~h}$ & 6.08 & 6.02 & 6.03 & 0.048 & 0.11 & 6.08 & 6.01 & 6.05 & 0.01 & 0.21 & 0.01 \\
\hline \multicolumn{12}{|c|}{ Barley ground through a 2-mm } \\
\hline \multicolumn{12}{|l|}{ DMD } \\
\hline $24 \mathrm{~h}$ & 56.7 & 61.3 & 57.6 & 0.82 & 0.25 & 57.8 & 59.9 & 57.8 & 1.47 & 0.999 & 0.55 \\
\hline \multicolumn{12}{|c|}{ Fermentation $\mathrm{pH}$} \\
\hline $6 \mathrm{~h}$ & 6.12 & 6.05 & 6.09 & 0.051 & $<0.01$ & 6.10 & 6.08 & 6.07 & 0.01 & 0.09 & 0.69 \\
\hline $24 \mathrm{~h}$ & 5.83 & 5.82 & 5.78 & 0.047 & 0.53 & 5.81 & 5.84 & 5.79 & 0.01 & 0.53 & 0.13 \\
\hline
\end{tabular}

Enzyme, cellulase from Acremonium cellulolyticus Y-94; FM, fresh matter; $p$, probability; L, linear; Q, quadratic; SEM, standard error of means.

feeding was 5.9 in Experiments 1 and 2 and 6.4 in Experiment 3. Thus, the results are applicable to feedlot finishing cattle fed barley grain based diets.

Anele et al $[14,20]$ reported effective rumen degradability $(20$ $\mathrm{h}$ mean retention time) of dry-rolled barley grain ranged from 228 to $250 \mathrm{~g} / \mathrm{kg}$ DM depending upon degree of processing, while Anele et al [20] reported a mean of $390 \mathrm{~g} / \mathrm{kg}$ DM for dry-rolled barley. Both those studies used rumen fluid from cattle fed $700 \mathrm{~g} / \mathrm{kg}$ DM barley silage rather than a diet of primarily barley grain as in the present study. Using a longer incubation time of $48 \mathrm{~h}$, Yang et al [21] reported in vitro DMD of a ground (1$\mathrm{mm}$ ) diet containing $451 \mathrm{~g} / \mathrm{kg}$ DM steam-rolled barley after 48 $\mathrm{h}$ of incubation ranged from 699 to $742 \mathrm{~g} / \mathrm{kg}$ DM. In Experiment 1 , in vitro DMD of ground barley grain after $24 \mathrm{~h}$ of incubation ranged from 285 to $359 \mathrm{~g} / \mathrm{kg}$ DM depending on extent of processing. These results are similar to the previous studies by Anele et al $[14,20]$ where a relatively short rumen incubation time was assumed, as was used in the present study. It should be noted that conditions of the in vitro technique differed (i.e., source of rumen fluid, substrate to ruminal fluid plus buffer ratio, processing of grain) from those used in other studies, thus it is somewhat difficult to directly compare our results to those in the literature. However, the emphasis of our study was on relative differences between treatments to determine optimum processing conditions.

\section{Particle size (Experiment 1)}

The major difference in in vitro DMD due to processing was between ground and dry-rolled barley which occurred at each incubation time, whereby DMD was substantially less for dryrolled than ground barley. Differences in DMD also occurred between 1- and 4-mm barley in the early incubation times (1 to $6 \mathrm{~h}$ ), but after $24 \mathrm{~h}$ of incubation these differences no longer existed. Thus, extent of particle size reduction during grinding had greatest effects in early stages of digestion, but were less important later in digestion. Anele et al [20] reported that processing (barley ground through 2 -mm screen versus dryrolled) increased the extent and rate of disappearance of DM and starch, which supports the results of the present study. Finely grinding barley is necessary when producing compound feed for beef cattle that is pelleted; however, grinding increases availability of starch. It can be concluded from the effects of grinding on increasing DMD, especially at early time periods, that feedlot cattle fed ground barley based diets may be at a greater risk of rumen acidosis because of greater starch availability. Koenig et al [7] reported that optimum processing index (defined as the weight of the grain after processing divided by the weight of the grain before processing) of dry-rolled barley was 0.61 when beef cattle were fed processed grain with barley silage $200 \mathrm{~g} / \mathrm{kg}$ DM. Based on the results of our study, it is recommended to feed dry-rolled barley to feedlot cattle rather than barley ground through 1-, 2-, and 4-mm screens. However, research to determine the desirable proportion of ground barley in compound feeds to support cattle health is needed.

Enzyme addition (Experiments 2 and 3) 
The enzyme product used in this study was selected because it had been shown previously to increase NDF degradation of rhodesgrass (Chloris gayana Kunth. cv. Callide) and guineagrass (Panicum maximum Jacq. cv. Natsukaze) [22] when used as a silage additive. In addition to endoglucanase activity, ENZ has greater $\beta$-glucosidase activity than some other products such as those derived from Trichoderma viride [23]. The linear increase in in vitro DMD of dry-rolled barley with increasing ENZ addition observed in Experiment 2 was confirmed in Experiment 3 , and was consistent with the observed increase in total gas production (trend only in Experiment 2) and decrease in fermentation $\mathrm{pH}$ in both experiments.

The observed responses for ENZ addition to barley grain are consistent with other in vitro studies. Yang et al [21] reported for dairy cows, addition of xylanase and cellulase increased total tract DM digestion of total mixed diet comprised of $451 \mathrm{~g} / \mathrm{kg}$ DM steam-rolled barley grain. Krause et al [11] reported acid detergent fiber digestion of rolled barley improved when using an enzyme mixture containing mainly cellulase and xylanase activities, while Colombatto et al [24] reported the contents of aNDF and hemicellulose of rolled barley were decreased with addition of xylanases and endoglucanases.

The minimal effects of ENZ when added to ground barley observed in Experiments 2 and 3 suggest that disruption of the fibrous hull via grounding negated the effect of cellulolytic enzymes. Grinding would be expected to remove the structural barrier to endosperm digestion by rumen microbes, although the chemical fiber matrix would remain unchanged. Applying ENZ to ground barley may have decreased the direct physical contact between enzyme and fibrous substrate, thereby reducing its effectiveness.

\section{Microwaving}

This study hypothesized that the effects of supplemented enzymes would be enhanced when used in combination with microwave treatment. Heat and moisture applied to grain can help gelatinize starch and may increase degradation by microorganisms in the rumen [2]. Contrary to our hypothesis there were no interactions between microwave treatment and enzyme addition. Yin and Walker [25] suggested that a hard gel is formed when amylose is released from starch granules during microwave heating, which could have rendered the microwave treatment ineffective in terms of increasing digestibility. Overall, the microwaving treatment as applied in the present study had relatively minor effects on barley grain fermentability, and cannot be recommended at this time.

\section{IMPLICATIONS}

Particle size reduction of barley by grinding increased in vitro DMD and gas production. Use of cellulolytic enzymes increased rumen disappearance of dry-rolled barley grain, but effects of enzymes on ground grain were minimal. Microwaving barley grain did not further improve in vitro fermentability of barley grain, even when used in combination with enzymes. The results indicate that cellulolytic enzymes can be used to increase the rumen availability of dry-rolled barley grain, but more extensive processing of grain eliminates the benefits of enzyme use.

\section{CONFLICT OF INTEREST}

We certify that there is no conflict of interest with any financial organization regarding the material discussed in the manuscript.

\section{ACKNOWLEDGMENTS}

The authors thank Mr. Alastair Furtado and Ms. Larissa Shalane Blair Smith for laboratory assistance, Mr. Merlin Anderson for fieldwork and Dr. Zhixiong He for statistical analysis assistance. The authors also thank Meiji Seika Pharma Co., Ltd. (Tokyo, Japan) for providing the enzyme product.

\section{REFERENCES}

1.United States Department of Agriculture. World agricultural production. [Internet] Foreign agricultural service, United states department of agriculture; 2015 [cited 2015 June 16]. Available from: http://www.fas.usda.gov/psdonline/circulars/production.pdf

2.Dehghan-banadaky M, Corbett R, Oba M. Effects of barley grain processing on productivity of cattle. Anim Feed Sci Technol 2007; 137:1-24.

3.Leek ABG, Callan JJ, Reilly P, Beattie VE, O’Doherty JV. Apparent component digestibility and manure ammonia emission in finishing pigs fed diets based on barley, maize or wheat prepared without or with exogenous non-starch polysaccharide enzymes. Anim Feed Sci Technol 2007;135:86-99.

4.Benabdeljelil K, Arbaoui MI. Effects of enzyme supplementation of barley-based diets on hen performance and egg quality. Anim Feed Sci Technol 1994;48:325-34.

5.Fuente JM, Perez de ayala P, Cillamide MJ. Effect of dietary enzyme on the metabolizable energy of diets with increasing levels of barley fed to broilers at different ages. Anim Feed Sci Technol 1995;56: 45-53.

6. Rode LM, Yang WZ, Beauchemin KA. Fibrolytic enzyme supplements for dairy cows in early lactation. J Dairy Sci 1999;82:2121-6.

7.Koenig KM, Beauchemin KA, Rode LM. Effect of grain processing and silage on microbial protein synthesis and nutrient digestibility in beef cattle fed barley-based diets. J Anim Sci 2003;81:1057-67.

8.Zhao YL, Yan SM, He ZX, et al. Effects of volume weight, processing method and processing index of barley grain on in situ digestibility of dry matter and starch in beef heifers. Anim Feed Sci Technol 2015;199:93-103.

9.McAllister TA, Rode LM, Major DJ, Cheng KJ, Buchanan-Smith JG. Effect of ruminal microbial colonization on cereal grain digestion. 
Can J Anim Sci 1990;70:571-9.

10. Beauchemin KA, Yang WZ, Rode LM. Effects of barley grain processing on the site and extent of digestion of beef feedlot finishing diets. J Anim Sci 2001;79:1925-36.

11. Krause M, Beauchemin KA, Rode LM, Farr BI, Nørgaard P. Fibrolytic enzyme treatment of barley grain and source of forage in high-grain diets fed to growing cattle. J Anim Sci 1998;76:2912-20.

12. Sadeghi AA, Shawrang P. Effect of microwave irradiation on ruminal dry matter, protein and starch degradation characteristics of barley grain. Anim Feed Sci Technol 2008;141:184-94.

13. Fujii T, Fang X, Inoue H, Murakami K, Sawayama S. Enzymatic hydrolyzing performance of Acremonium cellulolyticus and Trichoderma ressi against three lignocellulosic materials. Biotechnol Biofuels 2009;2:24-31.

14. Anele UY, Refat B, Swift ML, et al. Effect of bulk density, precision processing and processing index on in vitro ruminal fermentation of dry-rolled barley grain. Anim Feed Sci Technol 2014;195:2837.

15. Goering HK, Van Soest PJ. Forage fiber analysis (apparatus, reagents, procedures and some applications), Agricultural handbook No. 379, Washington, DC: ARS-USDA, 1970.

16. Mauricio RM, Mould FL, Dhanoa MS, et al. A semi-automated in vitro gas production technique for ruminant feedstuff evaluation. Anim Feed Sci Technol 1999;79:321-30.

17. AOAC. Official methods of analysis, 16th ed. Association of Official Analytical Chemists, Arlington, VA: AOAC International; 1995.

18. Van Soest PJ, Robertson JB, Lewis BA. Symposium: carbohydrate methodology, metabolism and nutrition. J Dairy Sci 1991;74:358397.

19. Getachew G, Crovetto GM, Fondevila M, et al. Laboratory variation of $24 \mathrm{~h}$ in vitro gas production and estimated metabolizable energy values of ruminant feeds. Anim Feed Sci Technol 2002;102:16980.

20. Anele UY, Refat B, Swift ML, et al. In vitro fermentation ruminal of ground and dry rolled barley grain differing in starch content. Anim Feed Sci Technol 2015;203:88-94.

21. Yang WZ, Beauchemin KA, Rode LM. A comparison of methods of adding fibrolytic enzymes to lactating cow diets. J Dairy Sci 2000; 83:2512-20.

22. Zhu Y, Nishino N, Xusheng G. Chemical changes during ensilage and in sacco degradation of two tropical grasses: rhodesgrass and guineagrass treated with cell wall-degrading enzymes. Asian-Australas J Anim Sci 2011;24:214-21.

23. Yamanobe T, Mitsuishi Y, Takasaki Y. Isolation of a cellulolytic enzyme producing microorganism, culture conditions and some properties of the enzymes. Agric Biol Chem 1987;51:65-74.

24. Colombatto D, Hervas G, Yang WZ, Beauchemin KA. Effects of enzyme supplementation of a total mixed ration on microbial fermentation in continuous culture, maintained at high and low pH. J Anim Sci 2003;81:2617-27.

25. Yin Y, Walker CE. A quality comparison of breads baked by conventional versus nonconventional ovens: a review. J Sci Food Agric 1995;67:283-91. 